\title{
An imagined community of practice: Online discourse among wheelchair users*
}

\author{
Leslie E. Cochrane (Williamsburg)
}

\begin{abstract}
People with disabilities often live in local communities primarily made up of people without disabilities: in the absence of a geographic community of people with disabilities, the internet becomes a valuable tool for connecting individuals across both local and global contexts. The power of computer-mediated communication (CMC) to allow individuals to interact both locally and globally has been well-studied in linguistics (e. g. Baron 2008; Page 2012), and this work has included the discourse of e-health (e. g. Hamilton 1998; Locher 2006, 2013) and the online discourse of people with disabilities (Al Zidjaly 2011, 2015). Less research has been done, however, on the implications of online discourse for understanding people with disabilities as a linguistic community.

This paper argues that the community of people with disabilities can be viewed from a linguistic perspective as an imagined community of practice: an imagined community, because members recognize their common belonging even if they do not interact locally (Anderson 1983); a community of practice, because members use recognizable, if not identical, disability practices and engage in shared sense-making (Eckert 2006; Eckert/McConnell-Ginet 1992). This understanding of the community of people with disabilities is evidenced in online blogs by wheelchair users.

A close discourse analysis of the blog posts shows shared sense-making around disability practices, even though individual bloggers' practices may vary according to their specific strategies for accommodation. In their posts, the bloggers construct their disability identities in terms of practice and imagine themselves to belong to a community that is distinguished by disability practice. The analysis reveals shared sense-making: in particular, the way that the bloggers position themselves in opposition to the societal discourse that people with disabilities are an inspiration to people without them. In this way, the bloggers demonstrate their membership within an imagined community of practice made up of people with disabilities.
\end{abstract}

\footnotetext{
* I am grateful for comments on earlier versions of this paper from the reviewers, the Georgetown University Health Discourse research group, and participants at the $3^{\text {rd }}$ International Conference on Language, Linguistics, Literature and Translation at Sultan Qaboos University, Oman.

Linguistik online 87, 8/17 - http://dx.doi.org/10.13092/lo.87.4177
}

CC by 3.0 


\section{Introduction}

People with disabilities ${ }^{1}$ often live in local communities primarily made up of people without disabilities: in the absence of a geographic community of people with disabilities, the internet becomes a uniquely valuable tool for connecting individuals across both local and global contexts. The power of computer-mediated communication (CMC) to allow individuals to interact both locally and globally has been well-studied in linguistics (e.g. Baron 2008; Page 2012). This work has included the discourse of e-health (e. g. Hamilton 1998; Locher 2006, 2013), though the still-evolving nature of discourse in new media warrants more investigation, as this special volume demonstrates. The online discourse of people with disabilities has been less well-studied (see Al Zidjaly 2011, 2015 for analysis of online disability discourse).

This study presents a close discourse analysis of blog posts written by wheelchair users with lifelong physical disabilities. In it, I show that the bloggers use disability practices to construct their identities as people with disabilities. Disability practices, as discussed in the next section, may include such diverse strategies for accommodation as using wheelchairs, employing a personal assistant, or scheduling periods for physical rest. Drawing on the concepts of community of practice (Eckert 2006; Eckert/McConnell-Ginet 1992) and imagined community (Anderson 1983), I propose that people with disabilities belong to an imagined community of practice, in which - although their individual disability practices vary - they define the community by practice and engage in shared sense-making about disability.

\section{Theoretical background}

\subsection{Disability as an identity}

I approach disability as an aspect of identity developed through lived experience and constructed in discourse. This approach stems from a larger view of disability as socially constructed. Scholars studying disability have long rejected the medical model of disability (Altman 2001; Oliver 1990; Shakespeare 2006). The medical model defines disability as a medical condition, locates it in an individual person, and predicts negative social consequences for the individual as a result of that condition. Societal (mis)understandings of disability often reflect this outdated, medicalized thinking, which has been closely connected to the stigmatization of disability and to attitudes of paternalism toward people with disabilities. In contrast, a social construction approach to disability holds that negative social consequences originate in the social world and not in the individual (Marks 1997; Minaire 1992). Although some models do highlight problems such as discrimination that people with disabilities face in their societies, disability is not understood as an individual problem to be solved. Rather, a social construction approach focuses on the ways in which people live their lives with long-term disabilities (Fougeyrollas/Beauregard 2001). Thus, this approach takes into account the wider sociocultural context and an individual's interaction with it. Yet the medical model

\footnotetext{
${ }^{1}$ It is my intention to use only terminology that is currently acceptable to most people with disabilities and to use it in ways that are in keeping with current scholarship on disability. I am aware of variations in usage (e. g. "people with disabilities" emphasizing personhood and "disabled people" emphasizing group membership), but not of any negative connotations to the terms I have used in this study.

In writing about people with disabilities, it should be noted that I do not have a physical disability myself. My understanding comes from friends and from my research participants with physical disabilities.
} 
ignored all social aspects of disability; early social models sometimes overlooked the physical aspects (Shakespeare 2006). The physical experience of disability, including having particular physical impairments and using particular disability practices, are integral to an individual's identity. More recent sociolinguistic studies of disability take into account how physical experiences such as using a visible assistive device interact with social experiences such as being called upon by strangers to explain disability practices (Ramanathan 2009; Ramanathan/Makoni 2007; Okada 2011).

Many socially constructed models of disability have multiple categories to represent these different aspects of disability (e. g. Altman 2001; Masala/Petretto 2013). For instance, Kasnitz/Shuttleworth (2001) identify the categories of impairment, functional limitation, disability, and handicap. Drawing on these past multi-category models, I propose a model designed to apply this approach to an individual's experience of physical disability (see Table 1). It is the individual's experiences of their medical condition(s), impairment(s), disability practices, and external factors that inform the identities they construct around disability and talk about in discourse. Thus, this model is useful for analyzing disability discourse.

\begin{tabular}{|l|l|l|l|l|}
\hline Category & Medical Condition & Impairment & Disability Practice & External Factors \\
\hline Definition & $\begin{array}{l}\text { Underlying } \\
\text { disorders, diseases, } \\
\text { or injuries }\end{array}$ & $\begin{array}{l}\text { Limitations in or } \\
\text { lack of function }\end{array}$ & $\begin{array}{l}\text { Habitual strategies } \\
\text { for accommodation } \\
\text { that an individual } \\
\text { employs in everyday } \\
\text { life }\end{array}$ & $\begin{array}{l}\text { Social and } \\
\text { environmental } \\
\text { conditions that impact } \\
\text { disability practices }\end{array}$ \\
\hline Examples & $\begin{array}{l}\text { e.g. cerebral palsy, } \\
\text { multiple sclerosis, } \\
\text { paraplegic paralysis }\end{array}$ & $\begin{array}{l}\text { e.g. spasticity, } \\
\text { inability to walk, } \\
\text { muscle weakness }\end{array}$ & $\begin{array}{l}\text { e.g. scheduling rest } \\
\text { periods, using a } \\
\text { wheelchair, } \\
\text { employing a personal } \\
\text { care assistant }\end{array}$ & $\begin{array}{l}\text { public transportation, } \\
\text { hiring policies and } \\
\text { attitudes, architectural } \\
\text { barriers }\end{array}$ \\
\hline
\end{tabular}

Table 1: Multi-category model of disability (Cochrane 2014)

All four categories of the model are socially constructed. As Kasnitz/Shuttleworth (2001) point out, medical diagnoses and functional limitations, as much as everyday practices and social factors, can only be understood in the sociocultural context in which they are experienced. The third category of the model is based on practice theory (Bourdieu 1972/1977; Bucholtz/Hall 2004): disability practices are habitual strategies for accommodation that an individual, given their particular impairments, chooses to employ on an everyday basis. These disability practices vary from individual to individual; the use of such practices is what characterizes having a disability. It is crucial to note that in this model each set of medical conditions, impairments, disability practices, and social and environmental factors is unique to an individual. No medical condition presupposes an impairment, nor vice versa. Most importantly, disability practice is not directly linked to an underlying medical condition. For example, a person who uses a power wheelchair may have cerebral palsy or muscular dystrophy; a person with multiple sclerosis may use a wheelchair full-time or not at all. Thus, I define a person with a physical disability as a person who uses an individual set of disability practices to move through everyday life. Drawing on the social construction approach to disability and my multi-category model of disability experience, I argue that having a disability can be understood as an identity that is discursively constructed. 


\subsection{People with disabilities as a community}

The discipline of disability studies often considers people with disabilities to be a minority group (Albrecht 2001; Hahn 1988, 1997). This approach is useful in scholarly work that applies models used for other minorities to people with disabilities. It is also applicable in social and political contexts to address the needs of people with disabilities as a group. In the disciplines of sociolinguistics and discourse analysis, however, it is typical to categorize people by the speech communities to which they belong. In addition to describing people with disabilities as a minority group, I propose to describe them in terms of the linguistic communities to which they belong.

One way to approach the community of people with disabilities is as a community of practice (Eckert/McConnell-Ginet 1992; Lave/Wenger 1991). The community of practice is modeled on the speech community (cf. Gumperz 1968/2009) but separate from its customary reliance on geographic or population boundaries; instead, the community is defined by shared practice and social interaction. Eckert (2006: 683), who has been influential in the spread of this model to sociolinguistics, defines community of practice as "a collection of people who engage on an ongoing basis in some common endeavor". This model has proved to be a robust construct for studying the language of groups of people, and it has many strengths for research about people with disabilities. I have stated that disability can be understood as habitual strategies for accommodation; in short, a set of practices. Given that perspective, it makes sense to consider whether people with disabilities can be viewed as part of communities of practice. Eckert (2006) observes that members of a community of practice have shared experiences and engage in shared sense-making. Because of its emphasis on practice and shared sense-making, the model seems suitable for understanding the disability community.

The principal weakness of treating people with disabilities as a community of practice is that the members do not necessarily engage with each other. In certain communities of practice, interaction may occur non-geographically. For instance Hamilton (1998) presents an online support group as a community of practice when she analyzes the narratives of bone marrow transplant survivors. Similarly, Locher (2006: 257) examines advice-seekers on an online health forum and "suggests that the notion of Community of Practice can be successfully applied to asynchronic and written forms of communication". It is generally understood, however, that members of a community of practice will interact with each other linguistically, and this is not necessarily the case for members of the disability community, even in an online setting. Any given blogger may not read or comment on the posts of any other blogger, even if both use a wheelchair. There is no evidence, for instance, that the authors of the three blogs examined here are aware of each other. Furthermore, it is problematic to assume that disability practices are all comparable; I have stated that sets of practices vary for each individual. Since bloggers with disabilities do not always interact with each other and do not necessarily share the same practices, understanding them as a community of practice requires the addition of another, complementary approach to linguistic communities.

In his work on nationalism and communities, Anderson (1983) proposes the construct of an imagined community. Members of an imagined community recognize that they belong to the same collection of people, even though that group includes people who they may never meet and with whom they may have little in common. Anderson (1983: 49) claims that "communi- 
ties are to be distinguished [...] by the style in which they are imagined". For example, Anderson points to a Javanese community that may define itself by kinship, as opposed to a French community that may define itself by social class. Though Anderson applies this to nationstates, an imagined community solves the problem of community members not engaging in any contact with each other.

To build on Anderson's argument, a community of people with physical disabilities may define itself by the use of practices - using accommodations to move through the world - even though these practices are not identical between individuals. I propose that people with disabilities recognize certain practices as belonging to the category of disability practices and imagine themselves to belong to a community that uses them. Thus, people with disabilities belong to an imagined community of practice: they may not interact with other members of the community or use identical practices, but they may still recognize themselves and others as belonging to such a community and sharing common experiences.

\section{$3 \quad$ Data and methodology}

The data consist of English-language blog posts by people who use wheelchairs. Herring et al. (2004: 1) define blogs as "frequently modified web pages in which dated entries are listed in reverse chronological sequence"; my data fall into the genre characterized as Personal Journals "in which authors report on their lives and inner thoughts and feelings" (2004: 6). The data were found by doing a simple search for wheelchair blog on the Google search engine from a United States location in Fall 2016. ${ }^{2}$ The criteria to include a blog in the corpus were:

1. The blogger was an adult who used a wheelchair (as apparent from their blog posts) and wrote posts in English.

2. The blog was viewable by the general public with no password, membership, or special status required; bloggers had no expectation of privacy when they wrote. ${ }^{3}$

3. The blog was authored by a single person (not an organization or group); had posts written within the last six months and over the course of at least a year; and was not primarily used as a platform to review products or travel, or to disseminate news and political discussion (though blogs could generate a profit or mention personal reactions to products, politics, etc.).

In this study, I choose to focus the analysis on blogs written by wheelchair users with lifelong physical disabilities only, that is, people who acquired their disabilities before, at, or just after birth. People who have disabilities as a permanent part of their lives have different experiences than those who acquire disabilities later in life. This important difference in life experience impacts identity construction. Thus, from my corpus of about $30 \mathrm{blogs}$, the three blogs analyzed in this study were the top three Google search results for bloggers with life-long

\footnotetext{
2 Thank you to my research assistants, Jessica Campbell and Abraham Kruger, for their help in identifying blogs that fit the criteria and collecting them in a corpus.

${ }^{3}$ Although the content of the blogs may address personal topics, the bloggers clearly address a public audience. Thus, I believe these blogs to fall into the category identified by Bolander and Locher (2014) as public in access and private in content, but without any expectation of privacy on the part of the bloggers.
}

ISSN 1615-3014 
disabilities: That Girl in the Wheelchair, ${ }^{4}$ The Squeaky Wheelchair, and A Writer in A Wheelchair. ${ }^{5}$ As it happened, all three of these bloggers identify as women. According to the context of the blogs, That Girl in the Wheelchair is a power wheelchair user from the southern United States who is in her thirties and has attended college and worked (at the least) parttime. Her underlying condition is muscular dystrophy. The Squeaky Wheelchair is a power wheelchair user from the western United States who was attending college when she began to blog. Her underlying condition is cerebral palsy. A Writer in A Wheelchair uses both a manual and power wheelchair, comes from the United Kingdom, and has worked (at the least) as a volunteer at multiple places. Her underlying condition is spastic cerebral palsy. This study highlights the texts in which the bloggers introduce themselves to their assumed audience of readers (the first post or About Me section of the blog), while also drawing on analysis of other blog posts.

Johnstone (1996: 24) argues that "discourse analysts' goal is to understand their data, rather than prove or disprove preformulated hypotheses or to create general predictive models". The small sample of blogs examined in this study is not sufficient to make generalizations about the discourse of wheelchair users. Rather, my analysis of the blog texts aims to understand the ways in which these bloggers construct their identities as people with disabilities. Two key concepts that the analysis makes use of are practice and positioning. Practice, described by Bourdieu (1972/1977) in his concept of habitus, is repeated social behavior. Bucholtz/Hall (2004: 378) point out that identity can form both "through the sedimentation of habitual action" and through the agentive choices of individuals to engage in particular communities of practice. In my analysis, both the blogger's habitual actions in the form of disability practices and their engagement with communities of practice are considered. Positioning, proposed by Davies and Harré as an alternative to concepts such as social role and footing (Goffman 1981) can be understood as "the discursive process whereby selves are located in conversations as observably and subjectively coherent participants in jointly produced storylines" (Davies/Harré 1990: 48). Identity emerges from the positionings instantiated in individual conversations or texts. Interlocutors may position each other and re-position themselves (Davies/Harré 1990; van Langenhove/Harré 1999); thus, positioning is a dynamic process that is negotiated between interlocutors. My analysis uses positioning as a lens to examine the locally-relevant discursively-created identities that are instantiated in the texts as bloggers construct their disability identities. These disability identities should thus be understood as "constellations of identities instead of individual, monolithic constructs" (De Fina et al. 2006: 2). Although the bloggers are not directly interacting with others, they write to an intended audience of readers and position themselves partly in relation to how they assume that audience positions them (Page 2012). My analysis shows how the bloggers use an outsider perspective - often the perspective of someone without a disability - to position themselves in ways that they can then negotiate. In the next sections, I use close discourse analysis (cf. Schiffrin 1994;

\footnotetext{
4 The blogger does not capitalize her blog title (that girl in the wheelchair) but puts it in distinctive fonts; I capitalize it as That Girl in the Wheelchair for clarity in this paper. The other blog titles follow the capitalization conventions of their authors.

${ }^{5}$ Because any portion of the text that is used in the analysis can be traced back to each blog by using a search engine, no attempt to disguise the names of the blogs would be successful. For this reason, I have used the actual names of the blogs as part of the analysis. However, I have not reproduced any information from the blog that is not relevant to the analysis of the bloggers' online disability identities (e. g. their real names when given).
}

ISSN 1615-3014 
Tannen/Hamilton/Schiffrin 2015) to demonstrate, first, how the bloggers use practice to do identity work and, second, how they understand their imagined community of practice.

\section{Constructing identities with disability practice}

Identities can be constructed, in part, through habitual practices (Bucholtz/Hall 2004; cf. Bourdieu 1972/1977). The bloggers with life-long disabilities emphasize disability practice when they construct disability identities, as in this example from A Writer in A Wheelchair:

(1) I use a wheelchair (specifically I have an Action 3 manual chair with a jay3 backrest for indoors, very short distances outdoors and/or when someone is with me and a Quickie Jive M Hybrid powerchair with a jay comfort back for everything else). (About $M e)^{6}$

Using a wheelchair is the disability practice that defines having a disability for A Writer in A Wheelchair, as the name of her blog itself suggests. This sentence above occurs on the About Me section of the blog immediately following the blogger describing herself as "having been disabled my whole life". Using a wheelchair is, first and foremost, what being disabled means for this blogger. Moreover, she is specific about which particular disability practices - habitual strategies for accommodation - she uses: a manual chair ...for indoors, a powerchair ...for everything else, and someone is with me pushing the manual chair for any long distance outdoors. These disability practices are unique to this individual with a disability.

In the continuation of her About Me section, A Writer in A Wheelchair does label her underlying medical condition and impairments, but she does so in response to assumed audiences. Noting that "I seemed to get asked a lot by strangers whether I've got MS or if I had polio", the blogger answers readers who might also wonder about her underlying medical condition (one category of my model of disability) by stating "What I've actually got is CP aka Cerebral Palsy". She goes on to explain the interaction between her medical condition and her impairments (another category of the model) by addressing another audience: "for CP geeks, those in the know and anyone else who might be interested, I have spastic CP ... it's pretty much mostly my legs but I have some hand/arm involvement cue arguments about whether that makes me a quad or not". This audience, unlike the strangers who ask about medical conditions, is knowledgeable enough about physical disability to have a hypothetical argument about the definition of quad (quadriplegic) based on what limbs are affected by spasticity. Explicitly identifying the audiences for information about medical condition and impairment, but not for practice, suggests that A Writer in A Wheelchair defines having been disabled my whole life in terms of her practices.

This emphasis on disability practice is evident in the names of the other two blogs, as well as of several blogs in the corpus (e.g. The Wheelchair Mommy, View from the Chair, Wheelchair Kamikaze, Powerchair Diaries, The Seated View). The Squeaky Wheelchair alludes to the English-language proverb, "the squeaky wheel gets the oil", meaning that people who speak up get what they want. The blogger uses this play on words to construct her identity in terms of both disability practice - their wheelchair - and another practice related to disability

\footnotetext{
${ }^{6}$ Bold emphasis is mine throughout the quoted data. Square brackets [ ] indicate my clarifications or ellipses within the text of the blog posts.
} 
- their disability advocacy. That Girl in the Wheelchair names her blog for her most visible disability practice. Instead of using the common title About Me, this page on her blog is called who's that girl?. The names of both the blog and the page emphasize an outsider perspective: someone - likely not a person in a wheelchair - seeing the blogger and labelling her by her disability practice. A Writer in A Wheelchair also alludes to this outsider perspective by subtitling her blog So much more than "that girl in the wheelchair". Thus the bloggers position themselves in relation to the perceived expectations of a (non-disabled) audience.

The bloggers frequently write posts that feature their disability practices alongside other areas of their lives. For example, A Writer in A Wheelchair describes experiences with a new power wheelchair in three blog posts. Two of these posts are connected by repetition in their titles, Miles on my Tyres (Miles 1) and Miles on My Tyres (Miles 2), although they were written two months apart. The third post, And I Would Walk 500 Miles... (Miles 3), alludes to a song lyric from "I'm Gonna Be (500 Miles)" by the Scottish band The Proclaimers, as the blogger mentions in the post. In all of these blog posts, A Writer in A Wheelchair describes her disability practices in order to position herself as an accomplished traveller. In the first post, she describes her everyday disability practices: "On a daily basis I would say I probably do two or three miles in the powerchair as it's probably somewhere in the region of two miles to do a round trip to town" (Miles 1). As in her About Me section, she is specific as to the uses of her different wheelchairs: "the only place I go with any regularity in the manual is sailing" (Miles 1). Because the new power wheelchair has the ability to count its mileage, the blogger and her mother have "been taking guesses as to how many miles I do in my chair in a year ever since" (Miles 1). The first post sets up the theme of traveling that continues across the subsequent entries.

A Writer in A Wheelchair positions herself as an accomplished traveller by recounting the miles she has travelled in her wheelchair as well as the places she has gone in the recent past. In the second post, she notes that the power wheelchair would have "a hell of a lot more miles in it if it counted ones done on the train" (Miles 2). The blogger also relates a time in which she was positioned as a traveller by an interlocutor: "one of them [refers to colleagues] was so shocked by how many miles I've done" (Miles 2). Positioning herself within a past event allows the blogger to construct her identity against the backdrop of a story world including third person characters who also position her as a traveller (see Schiffrin 1996 for storyworlds and Bamberg 2004 for positioning within them).

A Writer in A Wheelchair describes her traveling as an accomplishment: "I'm pleased by what I've done and achieved this month" (Miles 2). She also emphasizes the role of her disability practice of using a power wheelchair in making the accomplishment possible: "To have been so many places and done so many things that I wouldn't have been able to without a powerchair" (Miles 3). The third blog post is bookended by song lyrics that emphasize the distance the blogger has travelled: the title is And I Would Walk 500 Miles ... and the standalone last line is “...and I would walk 500 more!". By highlighting these lyrics throughout the post, A Writer in A Wheelchair both emphasizes her accomplishment of traveling 500 miles 
worth of pedestrian movement ${ }^{7}$ in her power wheelchair and draws intertextually on the cheerful, up-beat tone of the song. A Writer in A Wheelchair uses her disability practice to position herself as an accomplished traveller, a positioning that contributes to her overall identity work as a person with a disability.

The bloggers display their identities using disability practices, but they also create complex identities that include other kinds of practices. All three introduce themselves by name and age; two include location.

(2) A Writer in A Wheelchair: I'm [Una Smith]. I'm 34 and from the UK. (About Me)

(3) That Girl in the Wheelchair: Hi, I'm [Jenny]... As a 32-year-old native Nashvillian(ish), I am not the most amazing girl you have ever met. (who's that girl?)

(4) The Squeaky Wheelchair: My name is [Theresa] and I am a twenty-year-old college student. (first blog post, titled Hello)

By introducing themselves this way, the bloggers are conforming to a common pattern for blog introductions (Page 2012), as well as highlighting aspects of their identities aside from disability. That Girl in the Wheelchair alludes to an outsider perspective: the societal or Big-D Discourse (Gee 1996) - perpetuated by people without disabilities and commonly displayed in media discourses - that people with disabilities are an "inspiration" simply because they live with a physical disability (Grue 2016; Haller/Preston 2017). Disability scholars and activists generally condemn the Inspiration Discourse as objectifying people with disabilities in order to make people without disabilities feel good, and as perpetuating the medical model wherein disability is a deficit and an individual problem to be overcome (Haller/Preston 2017). That Girl in the Wheelchair's deliberate repositioning of herself as not the most amazing girl you have ever met creates a disability identity in which she uses the outsider perspective both in positioning herself in terms of her disability practice as that girl in the wheelchair and in re-positioning herself in opposition to the Inspiration Discourse.

The bloggers' discussion of practices other than disability practices displays their identities as complex and inclusive of - but not solely consisting of - their identities as people with disabilities (cf. Goffman 1963 on how a single (stigmatized) identity can "spoil" the construction of other identities). A Writer in A Wheelchair explains: "I've been referred to as a disability blogger and also a book blogger. Both are true but I prefer to just be called a blogger because I blog about my life" (About Me). She has been referred to as a book blogger in the past because of her participation on a website dedicated to reviewing books; she has been referred to as a disability blogger because she writes about having a disability on her personal blog. When A Writer in A Wheelchair repositions herself as a blogger as opposed to a disability blogger, the implication is that my life includes more than disability experiences.

In a similar way, That Girl in the Wheelchair explicitly claims that her blog is about aspects of her life other than disability:

\footnotetext{
${ }^{7}$ Although some wheelchair users use walk to refer to their movement in a wheelchair, A Writer in A Wheelchair uses the verb specifically to refer to walking with her legs, for example, "with a walker" or "in a swimming pool".
} 
(5) Trust, my chair is but a supporting character in my life. This blog is mostly about the loves of my life: Nashville, my mentally unstable mutts, my ginger boyfriend, my wild pack of friends, bargain shopping, reality TV that rots the brain, live Americana music, weird shit I find on the internet and really anything else that happens to strike my fancy. (who's that girl?)

She characterizes her disability as practice (my chair) but then lists other topics and practices (the loves of my life) that she intends to include on the blog. The Squeaky Wheelchair also lists aspects of her identity, including both identities related and unrelated to having a disability: "In addition to being a student, I am a passionate disability advocate, writer, food lover, and career cripple" (Hello). The blogger positions herself as a student foremost in her introductory post, as well as a writer and food lover. However, she also positions herself as a member of the disability community with the labels disability advocate and career cripple; these terms are discussed further in the next section. The Squeaky Wheelchair positions herself in terms of practices both related and unrelated to her disability status. Disability practices are a prominent theme throughout the blog posts, but the bloggers call attention to the fact that their disability practices - and still more their underlying medical conditions - are not the only facet of their identities.

All the bloggers position themselves in terms of their disability practices, by the titles of their blogs, by their emphasis on disability practices in their introductory posts, and by the themes of blog posts such as A Writer in A Wheelchair's posts on her power wheelchair's mileage. They make use of the perspectives of an assumed audience in order to position and re-position themselves as people with disabilities. At the same time, they explicitly expand their practices to take up positions beyond those related to having a disability. Thus, the bloggers create "constellations of identities" (De Fina et al. 2006: 2) in discourse about practices.

\section{$5 \quad$ Imagining a disability community of practice}

In her explanation of the community of practice, Eckert explains the notion of mutual sensemaking:

A community of practice engages people in mutual sense-making - about the enterprise they're engaged in, about their respective forms of participation in the enterprise, about their orientation to other communities of practice and to the world around them more generally.

(Eckert 2006: 683)

Although all people with disabilities do not necessarily engage in the same disability practices or interact with each other face-to-face, I propose that they can be understood as belonging to an imagined community (Anderson 1983) that defines itself by practice. The blog data reveals that the bloggers do imagine themselves to be part of a group of other people who participate in common experiences. Moreover, the data exhibits shared ideas about how this group is oriented to the world around it. Thus, the bloggers demonstrate remarkably similar sensemaking around disability practices.

The bloggers imagine a community of disability of which they are a part, and they refer to that community using in-group collective terms. They position themselves in ways that will be recognized by an in-group audience of other people with physical disabilities. For instance, The Squeaky Wheelchair refers to herself as a career cripple (Hello). The term cripple for a 
person with a physical disability is extremely derogatory when used by a person without a disability. Used by a person with a disability, cripple or the shortened crip may ${ }^{8}$ be taken as an in-group term or chosen self-identification (e.g. blog titles in my corpus include Bad Cripple, Claiming Crip, and Crip Confessions; cf. Mairs' 1996 essay on why she calls herself a cripple). The Squeaky Wheelchair's use of the word cripple positions her as a member of a group who has a right to use this term; her use of the modifier career highlights this as a permanent part of her identity. In a similar way, That Girl in the Wheelchair comments "Unlike many gimps, I don't care what kind of term you use: handicapped, cripple, disabled, or even that girl in the wheelchair" (who's that girl). The word gimps is also a term for a person with a physical disability that is derogatory when used outside the group. However, I have found it in frequent use in spoken discourse among wheelchair users with life-long disabilities in the United States (Cochrane 2014), as well as in my blog corpus (e.g. the blog title The Geeky Gimp). By positioning herself in relation to a larger group of many gimps, That Girl in the Wheelchair assumes a community of people who label themselves with this in-group term who are engaging in sense-making around what labels are acceptable for the group. The Squeaky Wheelchair frequently uses informal and in-group terms to refer to a group of people with disabilities. In her post titled Cripples at Christmas 2016 (Christmas), the blogger posts twelve photos of hand-drawn cartoons. In the post, she uses not only the term cripple, but also the referents wheelie (for a wheelchair user) and the disabled friends, and many of my dearest disabled cronies.

The bloggers discuss shared experiences among people with disabilities, despite their differences in disability practice. A Writer in A Wheelchair and The Squeaky Wheelchair both mention disability issues in their introductory posts. A Writer in A Wheelchair states: "I have a lot to say about disability issues from the annoying, funny scary to the happy ones and anything inbetween [sic]" (About Me). The idea that there are issues particular to disability suggests that the blogger imagines a community that shares common experiences. The Squeaky Wheelchair makes use of this idea in another way in her Christmas post, in which the cartoons she draws depict specific disability practices and experiences that people with disabilities might encounter. In one cartoon, she makes an intertextual reference to the song "The Twelve Days of Christmas", which has a lyric about "seven swans a-swimming", by captioning a picture of a swan with "The Swan with CP would not be a-swimming without her water wings" (Christmas). The humor of this cartoon draws not only on the intertextuality of the song lyric but also on the audiences' familiarity with using water wings (inflatable flotation devices on each arm) to swim. In the United States (where the blogger lives), water wings are typically used by young children and hardly ever by adults. Thus, the Squeaky Wheelchair is characterizing them as a disability practice that Swans with $C P$ use as a strategy for accommodation when swimming. By writing about disability practices experiences that they assume others have in common with them, the bloggers imagine a community of people with disabilities.

The bloggers also show a common "orientation to other communities of practice and to the world around them more generally" (Eckert 2006: 683). One way that the bloggers orient their community toward people without disabilities is the way they re-position themselves in

\footnotetext{
${ }^{8}$ Not all people with disabilities use, or approve of using, cripple and gimp as in-group terms.
}

ISSN 1615-3014 
opposition to the Inspiration Discourse. This discourse is a prevalent one; it is also one that the disability rights movement has purposely tried to combat. For example, The Squeaky Wheelchair mentions this societal discourse when she sarcastically states that "disabled folk [...] inspire others by doing inspiring things like drinking chocolate milkshakes and waking up in the morning" (Cute, Cuddly, and Crippled). Here she identifies two groups: disabled folk and others who are inspired by them. The Squeaky Wheelchair has several posts in which she talks about the concept of "inspiration porn". ${ }^{9}$ Two of these are titled It's Not My Job to "Inspire You": People with Disabilities and the Problem with "Inspiration Porn" (Inspiration 1) and Inspiration Porn: What's Not to "Like”? Well, A Lot.... (Inspiration 2). The second post has a link back to the first, making them a series. She defends her use of the provocative term porn by stating that "inspiration porn puts its subjects (disabled people) on display and exploits them for the benefit of viewers" (Inspiration 2). In both, The Squeaky Wheelchair discusses stories about people with disabilities in the news media and social media. In the second post, she particularly highlights a photo that was widely shared over social media in which a girl who uses a wheelchair goes to the prom (a yearly dance held at United States high schools) with a boy who does not use a wheelchair, with the caption "HE ASKED HER TO PROM EVEN IN HER CONDITION!". The blogger points out that "Our [referring to disabled people] participation should not be so unusual that it warrants media attention" (Inspiration 2). The photo and the fact that it was shared as a newsworthy item positions the group of people with disabilities as being exceptional in the realm of a typical high school event. From this exceptional inclusion comes the idea that the photo is inspirational. The overt point of the post is that people with disabilities are and should be included in communities with people without disabilities. At the same time, the blogger positions people with disabilities as a group that is oriented to the wider community in particular ways: "We are here in your schools, your workplaces, and your neighborhoods". The pronouns here position people with disabilities $(W e)$ as a distinct group that is nonetheless part of the wider community. From the assumption of exclusion in the captioned photo, The Squeaky Wheelchair re-positions the community of people with disabilities as an already-included part of the schools, workplaces, and neighborhoods thus making their inclusion unremarkable.

In her post “you go, girl” ...it's still a thing, That Girl in the Wheelchair tells a story in which she goes dancing at a club with friends: "All was going swimmingly until the first of many women approached me...patted me on the back and uttered the same three words: 'You go, girl." The blogger describes this comment from the women as "boiling down my having fun into some kind of weird inspirational PSA [Public Service Announcement, a television message aimed at a social issue]". In the story world, the women's characters position That Girl in the Wheelchair as an inspiration who should be encouraged with the expression you go girl. In contrast, the blogger positions her own character as a fun person. She repeats the word fun several times throughout the story: when she accepts the invitation, she "decide[s] to have fun"; just before the women come up to her, she "was just having fun"; every time the women come up to her, she was attempting "to let loose dancing or having fun". Outside the story world, the blogger considers the interaction:

\footnotetext{
9 The term "inspiration porn" for an online genre of the Inspiration Discourse originated with the Australian journalist, activist, and comedian Stella Young in 2012 (Grue 2016; Haller/Preston 2017).
}

ISSN 1615-3014 
(6) I guess if I can show them that disabled people come in all shapes and sizes and can be outgoing, fun people- then it's a good thing, right? Well, I guess.

The repeated hedge I guess casts doubt on whether the interaction was really a good thing. The post concludes with That Girl in the Wheelchair implying that what was said to her was not appropriate. In this small-d discourse, That Girl in the Wheelchair rejects you go girl as an uncomplicated statement of approval and instead links it to other instances of the Inspiration Discourse (some kind of weird inspirational PSA) and stereotypes about people with disabilities (not being fun people).

The similar way in which the two bloggers position themselves and others with disabilities in opposition to the Inspiration Discourse demonstrates shared sense-making. It shows a common orientation of the community of people with disabilities vis-a-vis other communities. All three bloggers imagine themselves as part of a disability community: a community defined by the disability practices that members engage in and characterized by shared sense-making and orientations to the wider world.

\section{Conclusion}

Many ways of understanding people with disability as a community have been proposed, ranging from the original social model (Oliver 1990), to the minority group model, to a cultural category (Shakespeare 1996). In some cases, a particular approach to the community is founded on the strategic essentialism (Bucholtz 2003) that seeks to advance the rights of people with disabilities in society. In discourse analysis, however, the common approach to understanding individuals and groups is in terms of identities and communities. To analyze people with disabilities as a community, I have argued that the concept of an imagined community of practice is authentic to the way disability is presented in discourse.

In my data, the three bloggers construct their identities as people with disabilities by positioning themselves in terms of their disability practices. They write about other practices as well, displaying complex "constellations of identities" (De Fina et al. 2006: 2) in their discourse. Although their individual strategies for accommodation vary, the bloggers see themselves as part of an imagined community that is distinguished by the use of disability practices. Thus, they belong to an imagined community of practice that engages in shared sense-making about disability. Online discourse allows the bloggers a forum to share their lives, thoughts, and feelings with an assumed wider audience of people both with and without disabilities. In their personal blogs, That Girl in the Wheelchair, The Squeaky Wheelchair, and A Writer in A Wheelchair write about their disabilities not as individual problems but as sociallyconstructed identities shaped within a community.

This paper has offered a close discourse analysis of online disability discourse focusing on three blogs out of a larger corpus. Possible next steps for the research are to incorporate additional data from other blogs in the corpus and to broaden the analysis to include comments and other interactive discourse on the blogs. Another avenue to explore, both in online and spoken disability discourse, is the societal Inspiration Discourse as it is presented - and resisted - in the individual discourses of people with disabilities. A more comprehensive analysis of the Inspiration Discourse could yield insight into how the community of people with disabilities engages in shared sense-making. 


\section{References}

Al Zidjaly, Najma (2011): "Managing social exclusion through technology: An example of art as mediated action". Disability Studies Quarterly 31/4. doi: 10.18061/dsq.v31i4.1716.

Al Zidjaly, Najma (2015): Disability, Discourse and Technology: Agency and Inclusion in (Inter)Action. New York: Palgrave Macmillan.

Albrecht, Gary L./Seelman, Katherine D./Bury, Michael (eds.) (2001): Handbook of Disability Studies. Thousand Oaks: Sage.

Altman, Barbara M. (2001): "Disability definitions, models, classification schemes, and applications". In: Albrecht, Gary L./Seelman, Katherine D./Bury, Michael (eds.): Handbook of Disability Studies. Thousand Oaks, Sage: 97-122.

Anderson, Benedict (1983): Imagined Communities: Reflections on the Origin and Spread of Nationalism. London: Verson.

Bamberg, Michael (2004): "Form and functions of 'slut bashing' in male identity constructions in 15-year-olds." Human Development 47: 331-353. doi: 10.1159/000081036.

Baron, Naomi (2008): Always on: Language in an Online and Mobile World. Oxford: Oxford University Press.

Bolander, Brook/Locher, Miriam A. (2014): "Doing sociolinguistic research on computermediated data: A review of four methodological issues". Discourse, Context \& Media 3: 14-26. doi: 10.1016/j.dcm.2013.10.004.

Bourdieu, Pierre (1972/1977): Outline of a Theory of Practice. Cambridge: Cambridge University Press.

Bucholtz, Mary (2003): "Sociolinguistic nostalgia and the authentication of identity". Journal of Sociolinguistics 7/3: 398-416. doi: 10.1111/1467-9481.00232.

Bucholtz, Mary/Hall, Kira (2004): "Language and identity". In: Duranti, Alessandro (ed.): A Companion to Linguistic Anthropology. Oxford, Blackwell: 369-394.

Cochrane, Leslie (2014): Telling Disability: Identity Construction in Personal and Vicarious Narratives. Unpublished $\mathrm{PhD}$ thesis. Georgetown University.

Davies, Bronwyn/Harré, Rom (1990): "Positioning: The discursive production of selves". Journal for the Theory of Social Behaviour 20/1: 43-63. doi: 10.1111/j.1468-5914.19 90.tb00174.x.

De Fina, Anna/Schiffrin, Deborah/Bamberg, Michael (2006): “Introduction”. In: De Fina, Anna/Schiffrin, Deborah/Bamberg, Michael (eds.): Discourse and Identity. Cambridge, Cambridge University Press: 1-26.

Eckert, Penelope (2006): "Communities of practice". In: Brown, Keith (ed.): Encyclopedia of Language and Linguistics. Amsterdam, Elsevier: 683-685.

Eckert, Penelope/McConnell-Ginet, Sally (1992): "Communities of practice: Where language, gender and power all live”. In: Hall, Kira/Bucholtz, Mary/Moonwomon, Birch (eds.): Locating Power: Proceedings of the Second Berkeley Women and Language Conference. Berkeley, University of California: 89-99.

Fougeyrollas, Patrick/Beauregard, Line (2001): "Disability: An interactive personenvironment social creation". In: Albrecht, Gary L./Seelman, Katherine D./Bury, Michael (eds.): Handbook of Disability Studies. Thousand Oaks, Sage: 171-194.

Gee, James Paul (1996): Social Linguistics and Literacies: Ideology in Discourses. London: Falmer Press. 
Goffman, Erving (1963): Stigma: Notes on the Management of Spoiled Identity. New York: Simon \& Schuster.

Goffman, Erving (1981): Forms of Talk. Philadelphia: University of Pennsylvania Press.

Grue, Jan (2016): “The problem with inspiration porn: A tentative definition and a provisional critique". Disability \& Society 31/6: 838-849. doi: 10.1080/09687599.2016.1205473.

Gumperz, John J. (1968/2009): “The speech community”. In: Duranti, Alessandro (ed.): Linguistic Anthropology: A Reader. Oxford, Blackwell: 66-73.

Hahn, Harlan (1988): "The politics of physical difference: Disability and discrimination". Journal of Social Issues 44/1: 39-47. doi: 10.1111/j.1540-4560.1988.tb02047.x.

Hahn, Harlan (1997): “Advertising the acceptably employable image: Disability and capitalism". In: Davis, Lennard J. (ed.): The Disability Studies Reader. New York, Routledge: 172-186.

Haller, Beth/Preston, Jeffrey (2017): “Confirming normalcy: 'Inspiration porn' and the construction of the disabled subject?". In: Ellis, Katie/Kent, Mike (eds.): Disability and Social Media: Global Perspectives. London, Routledge: 41-56.

Hamilton, Heidi E. (1998): "Reported speech and survivor identity in on-line bone marrow transplantation narratives". Journal of Sociolinguistics 2/1: 53-67. doi: 10.1111/14679481.00030 .

Herring, Susan C./Scheidt, Lois/Bonus, Sabrina/Wright, Edward L. (2004): "Bridging the gap: A genre analysis of weblogs". Proceedings of the 37th Hawai'i International Conference on System Sciences. Los Alamitos: IEEE Computer Society Press. doi: 10.1109/ HICSS.2004.1265271.

Johnstone, Barbara (1996): The Linguistic Individual: Self-Expression in Language and Linguistics. Oxford: Oxford University Press.

Kasnitz, Devva/Shuttleworth, Russell P. (2001): "Anthropology in disability studies". Disability Studies Quarterly 21/3: 2-17. doi: 10.18061/dsq.v21i3.289.

Lave, Jean/Wenger, Etienne (1991): Situated Learning: Legitimate Peripheral Participation. Cambridge: Cambridge University Press.

Locher, Miriam A. (2006): Advice Online: Advice-Giving in an American Internet Health Column. Amsterdam: Benjamins.

Locher, Miriam A. (2013): "Internet advice". In: Herring, Susan C./Stein, Dieter/Virtanen, Tuija (eds.): Pragmatics of Computer-Mediated Communication. Berlin, de Gruyter: 339362.

Mairs, Nancy (1996): Waist-High in the World: A Life among the Non-Disabled. Boston: Beacon Press.

Marks, Deborah (1997): "Models of disability". Disability and Rehabilitation 19/3: 85-91. doi: 10.3109/09638289709166831.

Masala, Carmelo/Petretto, Donatella Rita (2013): "Models of disability". In: Stone, John/Blouin, Maurice (eds.): International Encyclopedia of Rehabilitation. http://cirrie.buf falo.edu/encyclopedia/ [15.10.2015].

Minaire, Pieree (1992): "Disease, illness, and health: Theoretical models of the disablement process". Bulletin of the World Health Organization 70/3: 373-379. 
Okada, Hanako (2011): "Negotiating the invisible: Two women making sense of chronic illness through narrative”. In: McPherron, Paul/Ramanathan, Vaidehi (eds.): Language, Body, and Health. Berlin, de Gruyter: 145-170.

Oliver, Michael (1990): The Politics of Disablement. London: Macmillan Press.

Page, Ruth (2012): Stories and Social Media: Identities and Interaction. London: Routledge.

Ramanathan, Vaidehi (2009): Bodies and Language: Health, Ailments, Disabilities. Bristol: Multilingual Matters.

Ramanathan, Vaidehi/Makoni, Sinfree (2007): "Bringing the body back: The (mis)languaging of bodies in bio-medical, societal and poststructuralist discourses on diabetes and epilepsy". Critical Inquiry in Language Sciences 4/4: 283-306. doi: 10.1080/1542758 0701786885.

Schiffrin, Deborah (1994): Approaches to Discourse. Oxford: Blackwell.

Schiffrin, Deborah (1996): "Narrative as self-portrait: The sociolinguistic construction of identity". Language in Society 25: 167-203. doi: 10.1017/S0047404500020601.

Shakespeare, Tom (1996): "Disability, identity, and difference". In: Barnes, Colin/Mercer, Geoffrey (eds.): Exploring the Divide. Leeds, The Disability Press: 94-113.

Shakespeare, Tom (2006): "The social model of disability". In: Davis, Lennard J. (ed.): The Disability Studies Reader. London, Routledge: 197-203.

Tannen, Deborah/Hamilton, Heidi E./Schiffrin, Deborah (eds.) (2015): The Handbook of Discourse Analysis. Vol. 2. Oxford: Blackwell.

van Langenhove, Luk/Harré, Rom (1999): "Introducing positioning theory". In: Harré, Rom/van Langenhove, Luk (eds.): Positioning Theory. Oxford, Blackwell: 14-31.

\section{Bionote}

Leslie E. Cochrane is Lecturer of English and Linguistics at the College of William \& Mary in Virginia, United States, where she teaches courses in discourse analysis and sociolinguistics. She holds a masters in Linguistics from the University of Oxford and a doctorate in Linguistics from Georgetown University. Her dissertation, Telling Disability: Identity Construction in Personal and Vicarious Narratives, focused on the intersections of identity, narrative, and disability discourse. She has recently contributed chapters to Linking Discourse Studies to Professional Practice (2015) and Discourse Studies in Diverse Settings (forthcoming, ed. Grujicic-Alatriste), in which she analyzed the discourse of people with lifelong physical disabilities and proposed ways to share her research with the community. 